\title{
Molecular Cloning and Characterization of Fe-Superoxide Dismutase (Fe-SOD) from the Fern Ceratopteris thalictroides
}

\author{
Chen Chen and Quanxi Wang \\ Shanghai Normal University, Shanghai,
}

China

\section{Introduction}

Ferns are, evolutionarily, in a pivotal position between bryophytes and seed plants (Pryer et al., 2001). Fern gametophytes, like bryophytes, have no vascular system and live on substrate surfaces as small individual plants. However, fern sporophytes do have a vascular system enabling more vertical growth than the gametophytes, and resulting in a larger herbaceous plant form. The origins of plant vascular systems must have arisen during the evolution of primitive ferns (Kenrick, 2000). Ferns are historic plants and provide many facets of interest for researchers (Dyer, 1979; Raghavan, 1989). An especially important reason for choosing to study ferns is to gain insight into the evolution of higher plants .

Homosporous ferns, such as Ceratopteris, is a genus of homosporous ferns found in most tropical and subtropical area of the world (Lloyd, 1974, 1993; Masuyama, 1992). Ceratopteris are vascular plants that exhibit a biphasic life cycle with independent autotrophic haploid and diploid generations. Thus, they offer unique opportunities for studying a wide variety of experimental approaches and a large body for literature has been produced (Miller, 1986; Dyer, 1979) . In contrast to most other ferns, Ceratopteris possesses a fast life cycle time of less than $120 \mathrm{~d}$, can be cultured easily, and is readily amenable to genetic analyses (Hickok et al., 1987) Ceratopteris has been used as a model plant for many years in the study of genetics, biochemistry, cell biology, and molecular biology (Hickok et al., 1995; Chatterjee, 2000).

Plants are continually exposed to environmental fluctuations that lead to oxidative stress. Part of the damage caused by conditions such as intense light, drought, temperature stress, air pollutants etc. is associated with oxidative stress is an increase in the production of reactive oxygen species (ROS) (Levine A., 1999). Reactive oxygen species (ROS), such as hydrogen peroxide $\left(\mathrm{H}_{2} \mathrm{O}_{2}\right)$, superoxide anion $\left(\mathrm{O}_{2}-\right)$ and hydroxyl radical $(\mathrm{OH}-)$ are generated from normal metabolic process in all aerobic organisms. The damages from ROS include lipid peroxidation, cross-linking and inactivation of proteins, breaks in DNA and RNA, and cell death (Bestwick \& Maffulli, 2004; Fridovich, 1995). Aquatic organisms are often subjected to enhanced "oxidative stress" by ROS due to chronic exposure to pollutants in their environments (Marikovsky et al., 2003; Geret et al., 2004). To limit the harmful effect of ROS production and prevent damage from oxidative stress, cells have evolved to use antioxidant systems as part of the innate immune defense to maintain reactive oxygen species at low basal levels and protect themselves from the constant oxidative challenge (Geret et al., 2004; Manduzio et al., 2004). 
Superoxide dismutases (SODs) are a family of metalloenzymes that catalyze the disproportionation reactions of two superoxide anions to $\mathrm{H}_{2} \mathrm{O}_{2}$ and $\mathrm{O}_{2}$. SODs are classified into three groups according to their metal cofactors; copper-zinc (Cu/Zn-SOD), iron (Fe-SOD) and manganese (Mn-SOD) (Bowler et al., 1992; Scandalios, 1993). A fourth class of SODs with a nickel atom cofactor (Ni-SOD) was also identified, but so far, it has only been found in Streptomyces genera (Youn et al., 1996). The Fe-SOD is found in both prokaryotes and eukaryotes. It has not been found in animals or fungi, but is present in a limited number of seed plants ( e.g., Arabidopsis thaliana, tobacco (van Camp et al., 1990), soybean (Crowell \& Amasino, 1991 b), and rice (Kaminaka et al., 1999). Its absence in animal species has led researchers to propose that the Fe-SOD gene originated in the plastid before moving to the nuclear genome. Nonetheless, many seed plants, including maize, exhibit no Fe-SOD activity. The Fe- SOD activity in pea leaves was induced only by a deficiency of copper (Ayala \& Sandmann, 1988). An increase in the expression of FeSOD genes caused by copper deficiency was reported in tobacco leaves (Kurepa et al., 1997 a) and moss cells (Shiono et al., 2003) .However, such activity and transcription of the FeSOD gene has been detected in response to various stimuli and at certain developmental stages in barley (Casano et al., 1994), tobacco (Tsang et al., 1991; Kurepa et aI., 1997), and rice (Kaminaka et al., 1999).

Here we report the Fe-SOD levels from Ceratopteris thalictroides . The cloning of $\mathrm{Ct} \mathrm{Fe-}$ SOD may provide information to help further fern research in the area of functional genes.

\section{Materials and methods}

\subsection{Plant material and culture}

Spores of Ceratopteris thalictroides were collected from the Tianmu Mountains (Zhejiang, Chain) , sterilized with $2 \%$ sodium hypochlorite, and sown on to Murashige and Skoog (MS) solid medium (Sigma) with the addition of $1 \%$ pure agar (Sigma). All plants were cultured in an environmentally controlled chamber with $16 \mathrm{~h}$ light $26^{\circ} \mathrm{Cand} 8 \mathrm{~h}$ dark $20^{\circ} \mathrm{C}$ periods. After 21 days the gametophytes were used for RNA and protein extraction.

\subsection{Total RNA isolation}

$0.5 \mathrm{~g}$ gametophyte material was ground in liquid nitrogen with $0.25 \mathrm{~g}$ pvpp (polyvinylpolypyrrolidone) to a powder. The total RNA was extracted from this powder by using Trizol reagent (Invitrogen ) following the manufacturer's instructions.

\subsection{Touchdown PCR and RT-PCR}

Two degenerate primers P1: 5'-GARTTYCACTGGGGIAARCAYC-3'and P2: 5'GTARGCRTGCTCCCARACRTC-3' were designed based on highly conserved sequences to clone the mid-fragment of the SOD gene from Ceratopteris thalictroides. Touchdown PCR was performed using the following program: $5 \mathrm{~min}$ at $94^{\circ} \mathrm{C}(1$ cycle $)$, followed by $30 \mathrm{~s}$ at $94^{\circ} \mathrm{C}, 30 \mathrm{~s}$ at $59-67^{\circ} \mathrm{C}$, and $1 \mathrm{~min}$ at $72^{\circ} \mathrm{C}$ ( 35 cycles), and a final $20 \mathrm{~min} 72^{\circ} \mathrm{C}$ extension step. RNA used for RT-PCR was treated with RQ1 RNase-free DNase I (Promega, Madison, WI) to remove any possible contaminating DNA. RT-PCR was performed by using $500 \mathrm{ng}$ oligo(dT)12-18 primer for first-strand synthesis under standard conditions. Negative controls with water in place of reverse transcriptase were prepared for all samples in order to control for possible genomic DNA contamination of the RNA samples. 


\subsection{5'- and 3'-rapid amplification of cDNA ends}

To extend the Fe-SOD sequence in the 5'- and $3^{\prime}$-directions, we performed rapid amplification of cDNA ends (RACE) using a GeneRacer kit according to the manufacturer's instructions (Invitrogen). The 5'- and 3'- PCR was performed using touchdown PCR with the following respective primers; primer pair one (F5: 5'- CGACTGGAGCA CGAGGACACTG A-3'; R5:5'-TACGCAGTTTACATCCAGGT CG-3') and primer pair two (F3: 5'- GCTGTCAACGATACGTACGTAACG-3'; R3:5'-ACGCTACGT AACG GCATG -3'). Finally, one pair of gene-specific primers of full length Fe-SOD (FS:5'-CGGGATC CGATGGCCACGGCGACTTGCAGCTCTA-3';RS:5'-GCGTCGACCTATTTGTATTTATAT TGATCATCG-3') was designed based on the sequenced 5'- and $3^{\prime}$ - fragments. The fulllength cDNA of the Fe-SOD gene was amplified by PCR with these primers.

\subsection{Bioinformatic analysis}

Homologous sequences were identified by searching within the DDBJ/EMBL/ GenBank database using BLAST. Alignments were performed using the CLUSTAL W multiple sequence alignment program.

\subsection{Expression and purification of recombinant Fe-SOD}

The coding region of the Fe-SOD gene was amplified by PCR with primers. The amplified product was purified, digested with BamHI and SalI, and cloned into the pET32a vector which was predigested with the same restriction enzymes. The resulting plasmid was transformed into E. coli BL21 cells (Invitrogen), and positive clones were selected. Expression of the recombinant protein was induced by adding $1 \mathrm{mM}$ isopropyl $\beta$-Dthiogalactopyranoside (IPTG) at $37^{\circ} \mathrm{C}$ for $6 \mathrm{~h}$ and centrifuged at $6,000 \mathrm{rpm}$ for $10 \mathrm{~min}$ to collect cells. The cell pellets were washed in $1 \mathrm{ml}$ of Tris- $\mathrm{HCl}(\mathrm{pH} 7.4)$ and resuspended in 30 $\mathrm{ml}$ of binding buffer (10 mM NaH2PO4, $10 \mathrm{mM} \mathrm{Na2HPO} 4,500 \mathrm{mM} \mathrm{NaCl}, 30 \mathrm{mM}$ imidazole, $\mathrm{pH}$ 7.4) and sonicated for lysis. The suspension was centrifuged at 10,000 rpm for $10 \mathrm{~min}$ to clarify the enzyme solution. The recombinant protein was analyzed by $12 \%$ SDS-PAGE assay. The results show that the expressed proteins were in an insoluble form. The inclusion body was used to purify this recombinant protein. The 'Methods of Purification' were performed according to "Molecular Cloning: A Laboratory Manual Third Edition".

\subsection{Western blotting}

Five $\mu \mathrm{g}$ of the crude soluble protein samples was separated by using SDS polyacrylamide gel electrophoresis (SDS-PAGE) with 12\% seperating gels and 5\% collecting gels according to the standard protocol. Proteins were transferred to the polyvinylidene fluoride (PVDF; Millipore, U.S.A.) membrane and Fe-SOD protein was detected by polyclonal anti-FeSOD antibodies. Chemiluminescence was detected using the Amersham Enhanced Chemiluminescent (ECL) Plus Western Blotting Detection System (GE Healthcare Co. Ltd., U.K.) on X-ray film. The optical density from Western blot was conducted by using the Tannon Gel Image System (Tannon, Shanghai, China).

\subsection{Stress treatment and crude protein extraction}

In order to determine the function of Fe-SOD, the gametophytes were stressed under different illuminations and at low temperatures. The gametophytes were cultured in incubator at $26^{\circ} \mathrm{C}$ for one month. After that, half of them were put into a low temperature 
stress at $4^{\circ} \mathrm{C}$ for 72 hours. The other half were exposed to different illumination stresses at $26^{\circ} \mathrm{C}$. It was critical to maintain the same temperature during these stress events.

The gametophytes of Ceratopteris thalictroides were ground in liquid nitrogen. Total soluble proteins were extracted by sonication of the ground samples in Medium A ( $5 \mathrm{mM}$ sodium phosphate, $\mathrm{pH} 7.5,10 \mathrm{mM} \mathrm{MgCl}_{2}, 10 \mathrm{mM} \mathrm{NaCl}, 25 \%$ glycerol, $10 \mathrm{mM} \mathrm{HEPES}$ ) at $4^{\circ} \mathrm{C}$ for 15 min. Each extract was centrifuged at $13,000 \times \mathrm{g}$ for $15 \mathrm{~min}$ and the supernatant was collected. These proteins ware quantified spectrophotometrically via Bradford methods (Bradford, 1976) with bovine serum albumin (BSA) as the standard.

\section{Results}

\subsection{Cloning and characterization of Fe-SOD cDNA}

Following PCR with degenerate primers and sequencing analysis of selected clones, we obtained a partial gene sequence of about $458 \mathrm{bp}$ that putatively encoded for Fe-SOD. Sequencing analysis and Blast search of NCBI performed on the gene fragment revealed that it contained a partial sequence which was well conserved in Fe-SOD. The full-length gene sequence of Fe-SOD was about $1212 \mathrm{bp}$ and was finally obtained by RACE procedures. DNA sequencing analysis revealed that the amplified full-length sequence showed $77 \%$ identity to the Fe-SOD sequence from Matteuccia struthiopteris, and $71 \%$ identity to that of Pinus pinaster. The nucleotide sequence of the $\mathrm{Ct}$ Fe-SOD gene was deposited to the GenBank database under Accession No. HQ439554 Lane 1, 7: DNA Marker(DL2000, HindIII), Lane 2: PCR product of Fe-SOD, Lane 3: pET32a-FeSOD digested by BamHI/SalI , Lane 4: pET32a digested by BamHI/SalI, Lane 5: pET32a-FeSOD digested by BamHI , Lane 6: pET32a-FeSOD digested by SalI.

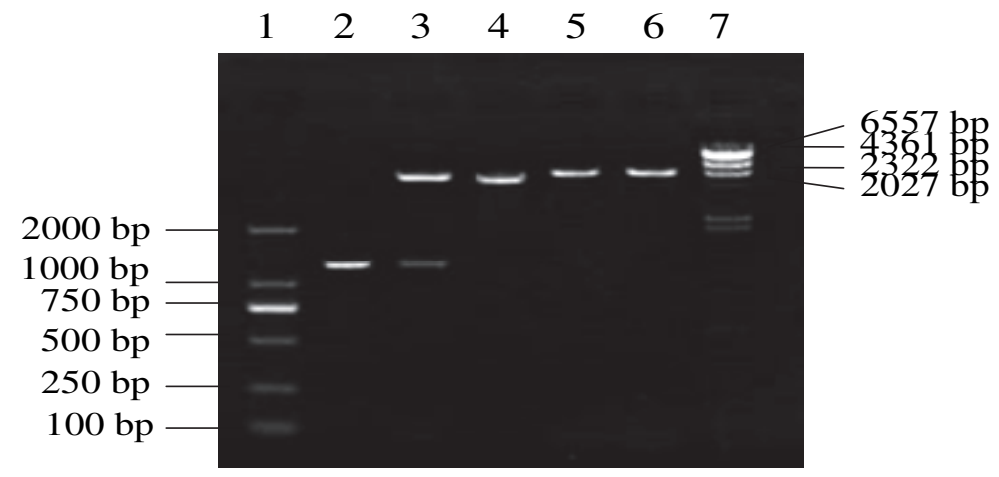

Fig. 1. Gel electrophoresis of pET32a-FeSOD after enzyme digestion.

\subsection{Expression and characterization of recombinant enzyme}

The gene encoding Fe-SOD harbored an open reading frame consisting of $798 \mathrm{bp}$ that encoded 266 amino acids. The estimated molecular weight of the protein was $43 \mathrm{kDa}$. The deduced amino acid sequence of Ct FeSOD was compared with the homologous enzymes from Matteuccia struthiopteris (MSFeSOD), Pinus pinaster (PpFeSOD) and Solanum lycopersicum (SIFeSOD). CtFeSOD showed as high as $82 \%$ identity with MSFeSOD, and 69\% identiy with PpFeSOD. 


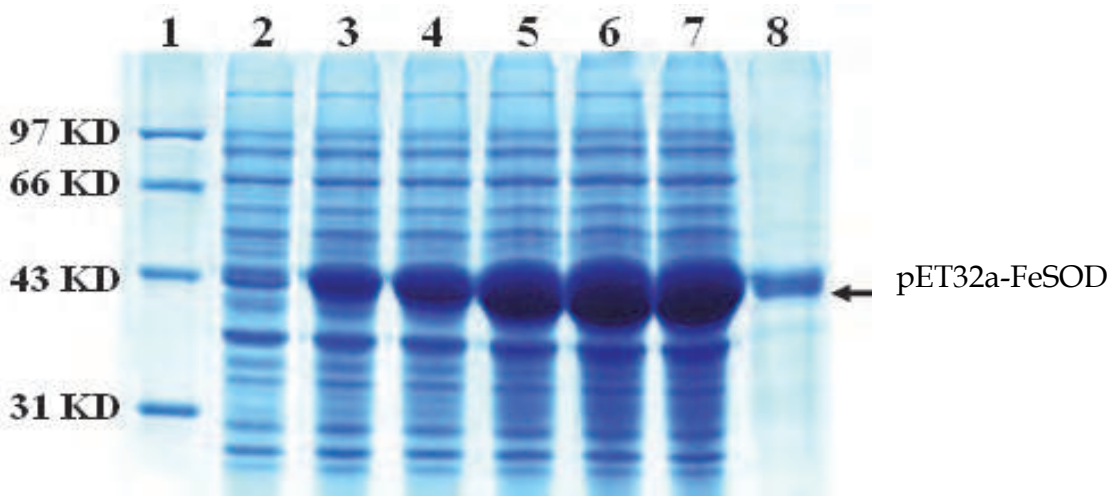

Fig. 2. Expression and purification of the recombinant Fe-SOD proteins in E. coli strain BL21.The arrow indicates recombinant Fe-SOD. The expression of the recombinant pET32a-fesod proteins in E. coli strain BL21. Lane 1, molecular weight standards; Lane 2,total protein of E. coli without induction; Lane 3,4,5,6,7 soluble protein of E.coli induced by $1 \mathrm{mM}$ IPTG at $37^{\circ} \mathrm{C}$ for $0.5,1,2,4$ and $6 \mathrm{~h}$ respectively. Lane 8: purified proteins. The separation gel of SDS-PAGE was with $12 \%$ polyacrylamide and stained with Coomassie Brilliant Blue.

Chlamy
Marchantia
Barbula
Pinus
Arabidopsis
Ceratopteris
Chlamy
Marchantia
Barbula
Pinus
Arabidopsis
Ceratopteris
Chlamy
Marchantia
Barbula
Pinus
Arabidopsis
Ceratopteris
Chlamy
Marchantia
Barbula
Pinus
Arabidopsis
Ceratopteris
chlamy
Marchantia
Pinus
Arabidopsis
Ceratopteris

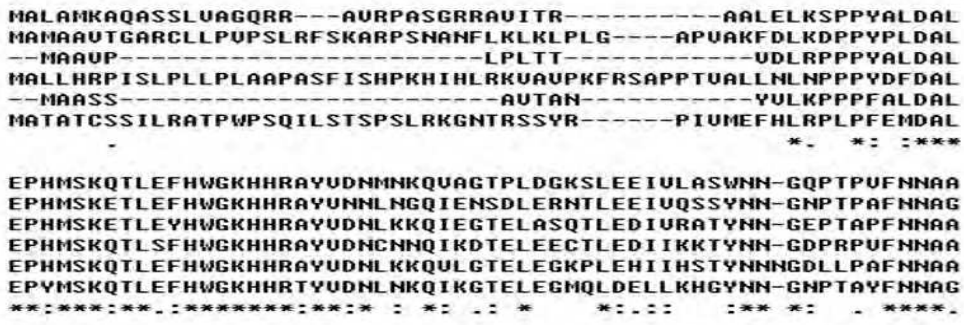

QUWNHTFFWESMKPNGGGAPTGALAEAITRDFG-SLDKFKEEFKQAGMTQFGSGWAWLNQ I WNHDFFWQSMKPGGGGPPT GEUAEL I NBDFG-SYDNFUKEFKAAGAT QFGSGWAWL-QAWNHEFFUL SMSPHGGKQPDGELMSLLKRDFG-SYDNFUKEFKQAGATQFGSGWAWL-QAWNHEFFWECMKPGGGKEPKEEILELIKRDFG-AYDEFLKEFKQASATQFESGWAWL-QAWHHEFFUESMKP QAWNHDFFWES I KPGGGKKPTGEULHLIERDFG-SFEAFUDEFKQAAATQFGSGWAWLUG

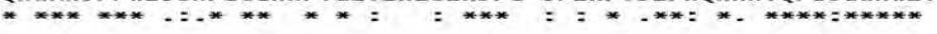

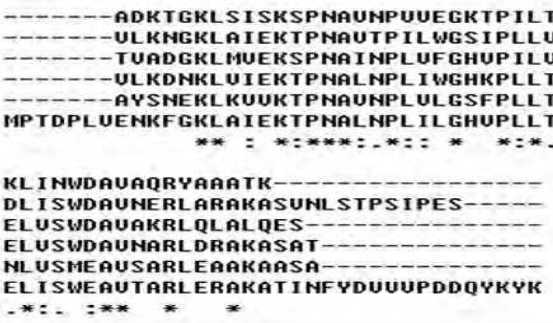

Fig. 3. Multiple sequence alignment of the deduced amino acid sequence of Fe -SOD . The identical residues among these Fe-SODs are marker by asterisks. Chlamydomonas reinhardtii(AABO4944.1), Marchantia polymorpha(BAC66948.1) , Barbula unguiculata (BAC66946.1), Pinus pinaster(AY 536055.1), Arabidopsis thaliana(NP 199923.1). 
Fe-SOD complete mRNA sequences from five species(Chlamydomonas reinhardtii, Marchantia polymorpha, Barbula unguiculata, Ceratopteris thalictroides, Pinus pinaster, Arabidopsis thaliana) were aligned in this study. Fe-SOD complete mRNA was highly homologous, having $65 \%$ homology of nucleotides within the coding regions. Amino acid sequence alignment from the same five species displayed five highly conserved domains in the Fe-SOD proteins: FNNA, FGSGW, WEHAYY, WNHHFF and HWGKH. In addition, FeSOD sequences of Ceratopteris thalictroides, Pinus pinaster and Arabidopsis thaliana encoded for a unique tripeptide ARL close to the carbox I terminus of the enzyme. ARL is the location signal of peroxisomes in cells. Although this sequence has been shown to direct the proteins to peroxisomes in other proteins, it has yet to be determined whether this is a functional sequence or not. The conserved ARL (or SRL) sequence is not present in the prokaryotic Fe-SOD proteins showing that it is not obligatory for the enzyme function (Van Camp et al., 1994). Experimental studies have shown that different types of SOD could exert their respective antioxidative functions, for example, Mn-SOD providing effective protection to DNA. Fe-SOD was primarily shown to protect the soluble proteins that were most sensitive to oxidation.

\subsection{Demonstration of Fe-SOD}

The specific Fe-SOD antibody (purchased from Agrisera) was used to demonstrate that the recombined protein was in fact Fe-SOD. Western blotting results showed that hybridization signals of recombined proteins and Fe-SOD from Ceratopteris thalictroides were placed in the same position. In addition, the same trend was found in the two proteins. This proved that the Fe-SOD gene in Ceratopteris thalictroides was expressed within transcribed levels and thus the recombined protein had to be Fe-SOD- based.

A

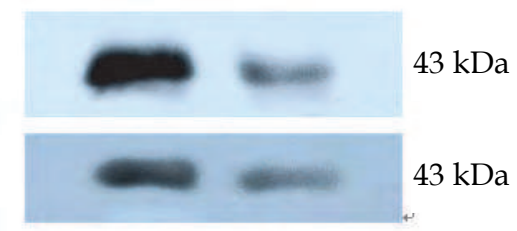

Fig. $4.10 \mu \mathrm{g}$ and $5 \mu \mathrm{g}$ crude protein was used for the western blotting to detect Fe-SOD expression level by twoantibodies respectively. Experiments were done at least in triplicates. Row A. recombinant pET32Fe-SOD antibody was used in this picture. Row B. Arabidopsis thaliana Fe-SOD antibody (Agrosera) was used in this picture.

\subsection{Fe-SOD expression during low temperature stress}

Gametophytes exposed to low temperature stress began to wither after $24 \mathrm{~h}$. According to this picture of western blotting, as stress time increased, the enzyme activity increased. Enzyme activity attained a maximum when the time was 8 hour, and then decreased. This result indicates that the Fe-SOD in gametophytes played an important role on resistance to adverse circumstances (low temperature). After 24 hours of cold treatment, the expressionof Fe-SOD was significantly reduced. We hypothesized that the clearance mechanism was restrained due to excessive ROS. The tendency of the gametophytes in Ceratopteris thalictroides was to first increase, then decrease. We saw the same tendency in pea plants under low temperature stress. 

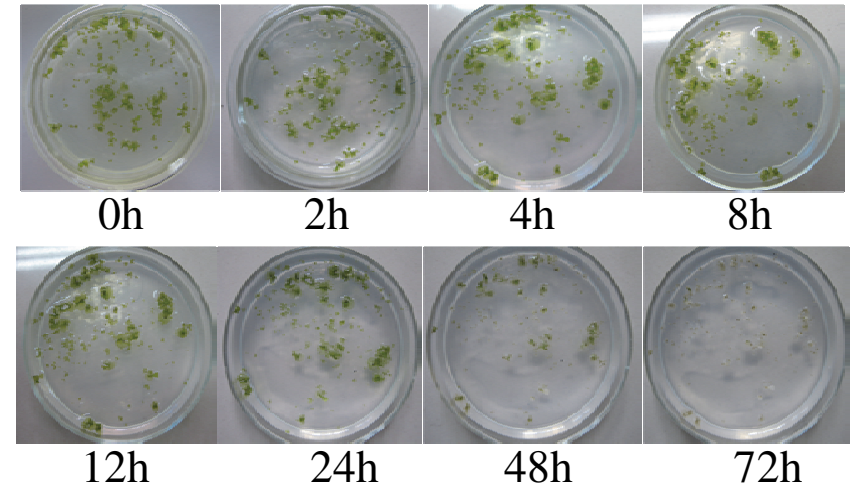

A.

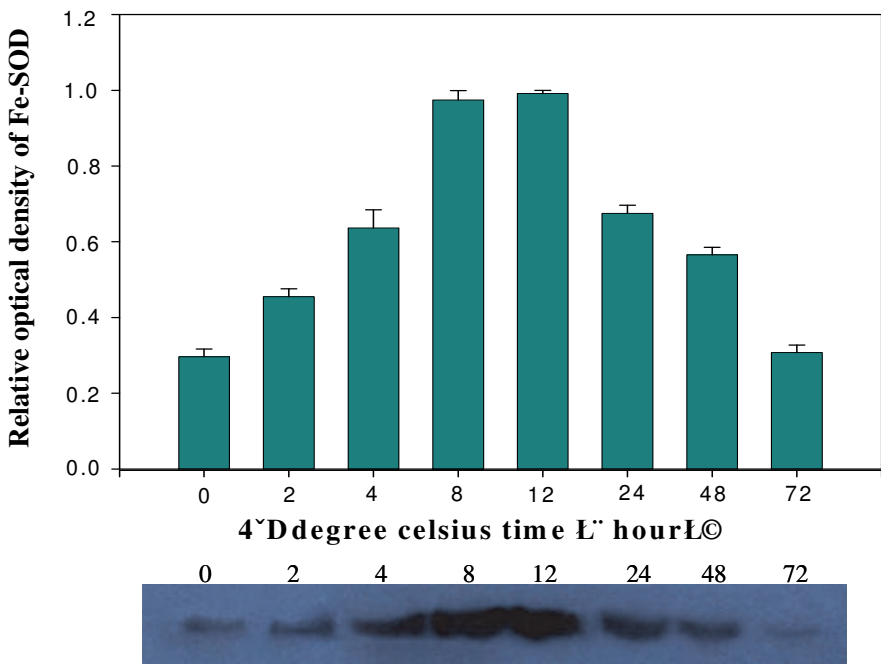

B.

Fig. 5. A. the gametophytes of Ceratopteris thalictroides in Chilling stress $\left(4^{\circ} \mathrm{C}\right)$. B.Expression of Fe-SOD in Ceratopteris thalictroides during chilling stress. $5 \mu \mathrm{g}$ crude protein was used for the western blottingto detect Fe-SOD expression level by using specific Fe-SOD antibody. Experiments were done at least in triplicates.

\subsection{Fe-SOD expression during illumination stress}

There was no difference in appearance between these gametophytes, but the results from western-blotting tests show that, when illuminated with $25 \times 10^{2}$ lux, the expression of FeSOD was the lowest. $25 \times 10^{2}$ lux was the light intensity in the incubator. The amounts of Fe-SOD in the other light illuminations were all greater than that of $25 \times 10^{2}$ lux. Whether the light source was strong or weak, expression of Fe-SOD was induced. This is because weak light interferes with plant photosynthesis, and strong light induces photo-inhibition of plants. The oxygen radicals in the plant cells increase in both cases. Fe-SOD expression 
levels were expected to increase in attempt to protect the plants against this adverse environment. We found that the amount of Fe-SOD in $600 \times 10^{2}$ lux was less than the amount found in $300 \times 10^{2}$ lux. We speculated that this was due to strong light damaging the scavenging systems of the active oxygen.
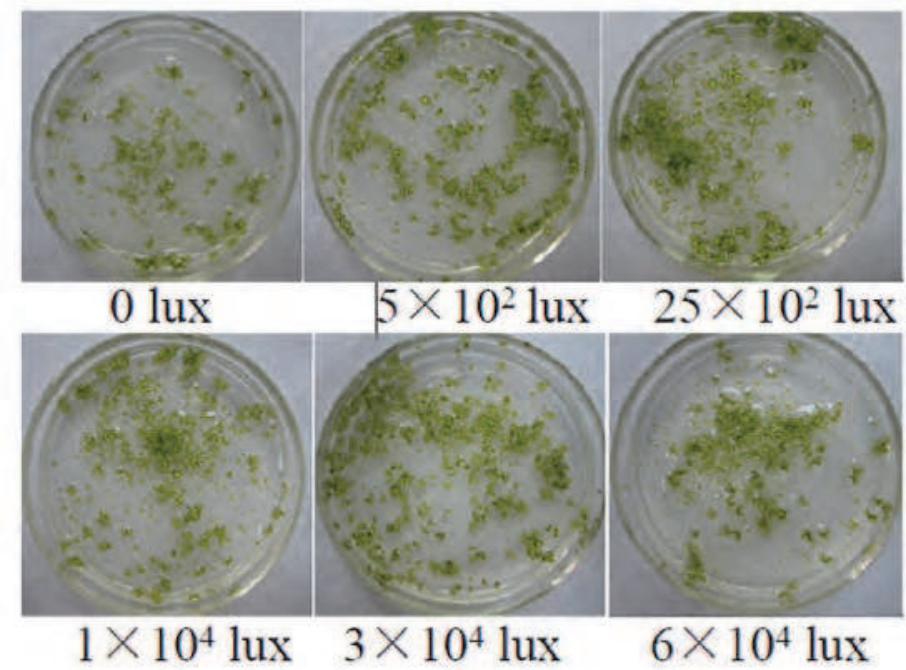

A.

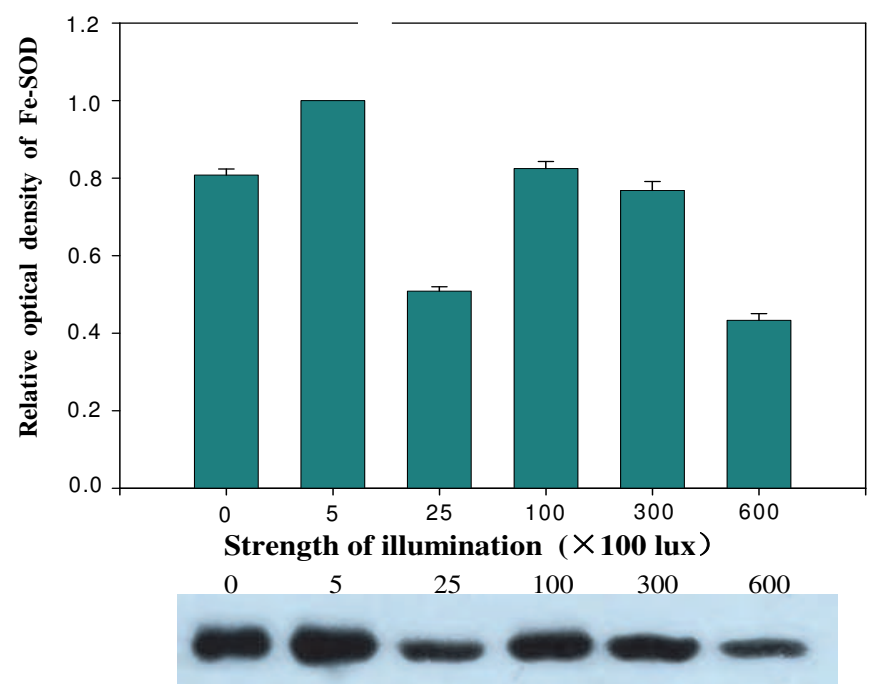

B.

Fig. 6. Expression of Fe-SOD in Ceratopteris thalictroides during Illumination stress. $5 \mu$ g crude protein was used for the western blotting to detect Fe-SOD expression level by using specific Fe-SOD antibody. Experiments were done at least in triplicates. 


\section{Discussion}

The absence of Fe-SOD in animals has given rise to the proposal that the Fe-SOD gene originated in the plastid and moved to the nuclear genome during evolution. Support for this theory comes from the existence of several conserved regions that are present in plant and cyanobacterial Fe-SOD sequence, but absent in non-photosynthetic bacteria (Bowler et al., 1994). Previous studies reported that, the majority of vascular plants examined contained both the $\mathrm{Cu}-\mathrm{Zn}$ and Mn enzymes but not the Fe enzyme. But Susan and Marvin considered that the gene for the Fe enzyme is present in all eukaryotic plants but not expressed. Environmental pressures could have resulted in the selection of a modified controlling region arising by mutation and allowing once more for expression of the enzyme (Susan \& Marvin, 1981). Kenichi Murao reported that Fe-SOD activity was not detected in extracts from the leaves of ferns, Equisetum arvense and Matteuccia struthiopteris. He thought the fern Fe-SOD gene was transcriptionally regulated by $\mathrm{Cu}$ (Kenichi Murao et al., 2004). But in this study we found Fe-SOD activity was detected in fern Ceratopteris thalictroides.

Photon energy is the only source of energy for plants but it can have harmful effects on plants if irradiance is lower or higher than the physiological requirement for plant growth and development (Long et al., 1996; Lawlor, 2001; Loomis \& Connor, 2003; Mandal \& Sinhá, 2004). High leaf irradiance reduces photosynthetic efficiency resulting in photodynamic degradation of the photosynthetic apparatus. Pigment-protein complexes present in photosystem $I I$ are highly sensitive to photo-damage triggered by the formation of reactive oxygen species (ROS) (Barber \& Anderson, 1992). Plants have developed enzymatic and non-enzymatic protection mechanisms against irradiance stress. Superoxide dismutases was part of the enzymatic antioxidative response system (Asada, 1996; Niyogi, 1999). SODs act as the first line defense against ROS, dismutating superoxide-radicals to $\mathrm{H}_{2} \mathrm{O}_{2}$ (Bowler et al., 1994; Kanematsu \& Asada 1994).These enzymes are in different cellular compartments and are controlled by a ROS gene network (Mittler et al., 2004). In the red alga Eucheuma denticulatum the photosynthetic production of $\mathrm{O}_{2}$ (by photosynthesis) under excessive light leads to an increase in the levels of ROSinducing SOD activity (Mtolera et al. 1995).

However The SOD enzyme not only consumes superoxide and thereby provides tolerance to oxidative stress, but also produces $\mathrm{H}_{2} \mathrm{O}_{2}$. It is tempting to speculate that an increased steady-state level of $\mathrm{H}_{2} \mathrm{O}_{2}$ or an increased flux through the $\mathrm{H}_{2} \mathrm{O}_{2}$ pool enhanced an acclimation process that enabled the plants to tolerate or repair freezing injury more effectively. $\mathrm{H}_{2} \mathrm{O}_{2}$ has potential toxicity in plants, but it may also have a number of regulatory roles. Recent reports suggest that $\mathrm{H}_{2} \mathrm{O}_{2}$ mediates some responses to pathogens (Chen et al.,1993), produces a transient $\mathrm{Ca}^{2+}$ surge, which is a known signaling component (Price et al., 1994), and initiates the production of other antioxidant enzymes during acclimation (Prasad, 1997). $\mathrm{H}_{2} \mathrm{O}_{2}$ is metabolized by a number of peroxidases using reducing equivalents to form water. Mcord and Fridawich believe that, the removing process and generation process of ROS were exist simultaneously in plant cells. The ROS would generate and membrane lipid peroxidation increased while the plant in adversity stress (Mocord \& Ries, 1997 ; Pryor WA, 1977). The increase of ROS in cells would damage DNA and membranes, thus affecting the protein synthesis. This could lead to metabolic rate reduction and cell death. Certain enzymes (SOD, for example) are able to remove ROS to protect cells from injury. This is referred to as the "protectase system". 
In conclusion, our study described the cloning, expression and characterization of the FeSOD gene from the fern Ceratopteris thalictroides. Sequence analysis of CtFe-SOD predicted that this gene encodes a protein of about $43 \mathrm{kDa}$ and shows high similarity to most known Fe-SOD genes, sharing five highly conserved domains that are most likely essential for enzyme activity. Certainly, further investigation is warranted to determine the functional and biological significance of $\mathrm{CtFe}-\mathrm{SOD}$, in particular its role in stress resistance.

\section{References}

Asada, K. (1996). Radical production and scavenging in the chloroplasts, in Baker, NR. (ed.), Phytosynthesis and the Environment, Kluwer Academic Publ., Dordrecht -Boston London, pp.123-150

Asano, CS., Okamoto, OK., Hollnagel, HC., Stringher, CG., Oliveira, MC. \& Colepicolo, P. (1996). The activity of superoxide dismutase oscillates in the marine dinoflagellate Gonyaulax Polyedra, Ciência e Cultura 48: 64-67

Ayala, MB. \& Sandmann, G. (1988). Activities of Cu-containing protein in Cu-depleted pea leaves, Physiol Plant 72: 801-806

Barber, J. \& Andersson, B. (1992). Too much of a good thing: light can be bad for photosynthesis, Trends biochem. Sci. 17: 61-66

Bestwick, CS. \& Maffulli, N. (2004). Reactive oxygen species and tendinopathy: do they matter? Br J Sports Med 38:672-4.

Bowler, C., Van Montagu, M. \& Inzd, D. (1992). Superoxide dismutase and stress tolerance, Ann. Rev. Plant Physiol 43:83-116

Seandalios, J. (1993). Oxygen stress and superoxide dismutase. Plant Physiol 101:7-12.

Bowler, C., Van Camp, W., Van Montagu, M. \& Inzé, D. (1994). Superoxide dismutase in plants, CRC crit. Rev. Plant Sci. 13: 199-218

Bradford, MM. (1976). A rapid and sensitive method for the quantitation of microgram quantities of protein utilizing the principle of protein-dye binding, Anal. Biochem 72:248-254

Casano, LM., Martin, M. \& Sabater, B. (1994). Sensitivity of superoxide dismutase transcript levels and activities to oxidative stress is lower in mature-senescent than in young barley leaves, Plant Physiol 106:1033-1039

Chatterjee, A. \& Roux, S.J. (2000). Ceratopteris richardii: a productive model for revealing secrets of signaling and development, J.plant Groeth regul 19:284-289

Chen, Z., Silva. H., \& Klessig, DF. (1993). Active oxygen species in the induction of plant systemic acquired resistance by salicylic acid, Science 262: 1883-1886

Colepicolo, P., Camarero, VCPC. \& Hastings, JW. (1992). A circadian rhythm in the activity of SOD in the photosynthetic alga Gonyaulax polyedra, Chronobiol. Int. 9:266-268

Crowell, D.N. \& Amasino, R.M. (1991). Induction of specific mRNAs in cultured soybean cells during cytokinin or auxin starcation, Plant Physiology 95:711-715

Crowell, D.N. \& Amasino, R.M. (1991 b). l'-lucleotide sequence of an iron superoxide dislllutase complementary DNA from soy-bean, Plant Physiol 96: 1393-1394

Dyer, AF. (1979). The experimental biology of ferns, Academic Press, London, pp. 657

Fahrendorf, T., Ni, WT., Shorrosh, BS. \& Dixon, RA. (1995). Stress responses in alfalfa (Medicago sativa L.)19: transcriptional activation of oxidative pentose phosphate pathway genes at the onset of the isoflavonoid phytoalexin response, Plant Mol Biol 28: 885-900

Fridovich, I. (1995) Superoxide radical and superoxide dismutases, Annu Rev Biochem 64:97-112 
Geret, F., Manduzio, H., Company, R., Leboulenger, F., Bebianno MJ. \& Danger, JM. (2004) Molecular cloning of superoxide dismutase (Cu/Zn-SOD) from aquatic mollusks, Mar Environ Res 58:619-23

Hickok, LG., Warne, TR. \& Slocum, MK. (1987). Ceratopteris richadii: applications for experimental plant biology, Am J Bot 74:1304-1316

Hickok, LG., Wame, TR. \& Fribourg, RS. (1995). The biology of the fern ceratopteris and its use as a model system, Int.J.Plant.Sci 156:332-345

Hollnagel, HC., Di Mascio, P., Asano, CS., Okamoto, OK., Stringher, CG., Oliveira, MC. \& Colepicolo, P. (1996). The effect of light on the biosynthesis of b-carotene and superoxide dismutase activity in the photosynthetic alga Gonyaulax polyedra, Braz. J. med. biol. Res. 29:105-110

Hunt, JS. \& Sipes, SD. (2001). Horsetails and ferns are a monophyletic group and the closest relatives to seed plants, Nature 409:618-622

Kaminaka, H., Morita, S., Tokumoto, M., Yokoyama, H., Masumura, T. \& Tanaka, K. (1999). Molecular cloning and characterization of a cDNA for an iron-superoxide dismutase in rice (Oryza sativa L.), Biosci Biotechnol Biochem 63: 302-308

Kanematsu, S. \& Asada, K. (1994). Superoxide dismutase, in: Fuku, T., Soda, K. (ed.), Molecular Aspects of Enzyme Catalysis, Kodansha, Tokyo, pp. 191-210

Kenichi Murao, Masayuki Takamiya, \& Kanji Ono. (2004). Copper eficiency induced expression of Fe-superoxide dismutase gene in Matteuccia struthiopteris, Plant Physiology and Biochemistry 42 143-148

Kenrick, P. (2000). The relationships of vascular plants.Phil Trans R Soc Lond B 355:847-855.

Kurepa, J., Van Montagu, M. \& Inzé,D. (1997 a). Expression of sodCp and sodB genes in Nicotiana tabacum: effects of light copper excess, J. Exp. Bot 48:2007-2014.

Kurepa, J., Herouart, D., Van Montagu, M. \& Inze, D. (1997 b). Differential expression of $\mathrm{CuZn}$-and $\mathrm{Fe}$ superoxide dismutase genes of tobacco during development, oxidative stress, and hormonal treatments, Plant Cell Physiol 38:463-470

Lawlor, DW. (2001). Photosynthesis: Molecular, Physiological and Environmental Processes, Springer-Verlag, New York

Levine, A. (1999). Oxidative stress as a regulator of environmental responses in plants, in Lerner HR.(ed.), Plant responses to environmental stress, New York: Marcel Dekker Inc, pp. 247-264

Lloyd, RM. (1974). Systematics of the genus Ceratopteris Brongn. (Parkeriaceae). II Taxonomy.Brittonia 26:139-160

Lloyd, RM. (1993). Parkeriaceae Hooker, water fern family. Pages North of Mexico.Vol 2. Pteridophytes and Gymnosperms. Oxford University Press, New York

Long, SP., Farage, PK. \& Garcia, RL. (1996). Measurement of leaf and canopy photosynthetic CO2 exchange in the field, J. exp.Bot 47:1629-1642

Loomis, RS. \& Connor, DJ. (2003). Crop Ecology: Productivity and Management in Agricultural Systems, Cambridge University Press, Wiltshire

Mandal, KG. \& Sinhá, AC. (2004). Nutrient management effects on light interception, photosynthesis, growth, dry-matter production and yield of Indian mustard (Brassica juncea), J.Agron. Crop Sci. 190:119-129

Manduzio, H., Monsinjon, T., Galap, C., Leboulenger, F. \& Rocher, B. (2004). Seasonal variations in antioxidant defences in blue mussels Mytilus edulis collected from a polluted area: major contributions in gills of an inducible isoform of $\mathrm{Cu} / \mathrm{Zn}$ superoxide dismutase and of glutathione S-transferase, Aquat Toxicol 70:83-93 
Marikovsky, M., Ziv, V., Nevo, N., Harris-Cerruti, C. \& Mahler, O. (2003). Cu/Zn superoxide dismutase plays important role in immune response, J Immunol 170:2993-3001

Masuyama, S. (1992). Clinal variation of frond morphology and its adaptive implication in the fern Ceratopteris thalictroides in Japan, Plant Species Biol 7:87-96

Miller, Jh. (1968). Fern gametophytes as experimental material, Bot Rev 34:316-426

Mittler, R., Vanderauwera, S., Gollery, M. \& Breusegem, FV. (2004). Reactive oxygen gene network of plants, Trends Plant Sci. 9: 490-498

Mocord, Ries sk. (1997). Pwrification and quantiative relationship with eater - soluble pratein in seedlings, plant physiol. 59:315 - 318

Mtolera, MSP., Collén, J., Pedersen, M. \& Semesi, AK. (1995). Destructive hydrogen peroxide production in Eucheuma denticulatum (Rhodophyta) during stress caused by elevated $\mathrm{pH}$, high light intensities and competition with other species, Eur. J.Phycol. 30:289-297

Niyogi, KK. (1999). Photoprotection revisited: Genetic and molecular approaches, Annu. Rev. Plant Physiol. Plant mol. Biol. 50: 333-359

Prasad, TK. (1997). Role of catalase in inducing chilling tolerance in pre- emergent maize seedlings, Plant Physiol 114: 1369-1376

Price, AH., Taylor, A., Ripley, SJ., Griffiths, A., Trewavas, AJ. \& Knight, MR. (1994). Oxidative signals in tobacco increase cytosolic calcium, Plant Cell 6:1301-1310

Pryer, KM., Schneider, H., Smith, AR., Cranfill, R., Wolf, PG. \& Raghavan, V. (1989). Developmental biology of ferns. Cambridge University Press, New York

Pryor, WA. (1977). Free Redical in Biology Volume III, Academic Press Incorporated,New York, NY

Robertson, D. Davies, DR., Gerrish, C., Jupe, SC. \& Bolwell, GP. (1995). Rapid changes in oxidative metabolism as a consequence of elicitor treatment of suspension-cultured cells of French bean (Phaseolus vulgaris L), Plant Mol Biol 27: 59-67

Salin, ML. \& Bridges, SM. (1981). Absence of the iron-containing superoxide dismutase in mitochondria from muatard(Brassica campestris), Biochemical Journal 195: 229-233.

Shiono, T., Nakata, M., Yamahara, T., Matsuzaki, M., Deguchi, H. \& Satoh, T. (2003). Repression by $\mathrm{Cu}$ of the expression of Fe-superoxide dismutase of chloroplasts in the moss Barbula unguiculata but not in the liverwort Marchantia paleacea var. diptera, J. Hattori Bot. La. 93:141-153

Susan, MB \& Marvin, LS. (1981)Distribution of iron-containing Superoxide dismuasein vascular plant, Plant Physiol $68: 275-282$

Tsang, EWT., Bowler, C., Herouart, D., van Camp, W., Villaroel, R., Genetello, C., Van Montagu, M. \& Inze, D. (1991). Differential regulation of superoxide dismutase in plants exposed to environmental stress, Plant Cell 3:783-792

Van Camp, W., Bowler, C., Viliarroel, R., Tsang, EWT., Montagu, MY. \& Inze, D. (1990a). Characterization of iron superoxide dismutase cDNAs from plants obtained by genetic complementation in Escherichia coli, Proc Natl Acad Sci USA 84: 9903-9907

Van Camp, W., Bowler, C. \& Villarroel, R. (1990 b). Characterization of iron superoxide dismutase cDNAs from plants obtained by genetic complementation in Escherichia coli, Plant Physiology 112:1703-1714

Van Camp, W., Willekens, H. \& Bowler, C. (1994). Elevated levels of suoeroxide dismutase protect transgenic plants against ozone damage, Bio Technology 12:165-168

Youn, HD., Kiln, EJ., Roe, JH., Hah, YC. \& Kang, SO. (1996). A novel nickel-containing superoxide dismutase from Streptomyces spp, J. Biochem 318:889-896 


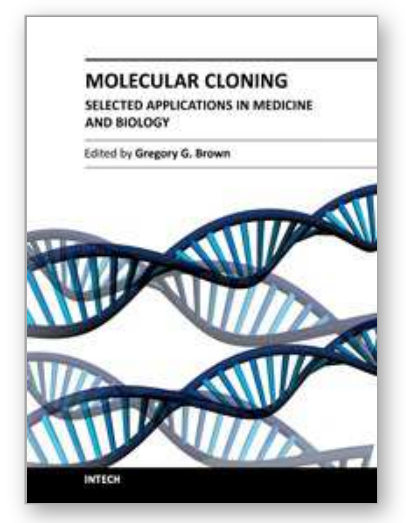

\author{
Molecular Cloning - Selected Applications in Medicine and Biology \\ Edited by Prof. Gregory Brown
}

ISBN 978-953-307-398-9

Hard cover, 324 pages

Publisher InTech

Published online 12, October, 2011

Published in print edition October, 2011

The development of molecular cloning technology in the early 1970 s created a revolution in the biological and biomedical sciences that extends to this day. The contributions in this book provide the reader with a perspective on how pervasive the applications of molecular cloning have become. The contributions are organized in sections based on application, and range from cancer biology and immunology to plant and evolutionary biology. The chapters also cover a wide range of technical approaches, such as positional cloning and cutting edge tools for recombinant protein expression. This book should appeal to many researchers, who should find its information useful for advancing their fields.

\title{
How to reference
}

In order to correctly reference this scholarly work, feel free to copy and paste the following:

Chen Chen and Quanxi Wang (2011). Molecular Cloning and Characterization of Fe-Superoxide Dismutase (Fe-SOD) from the Fern Ceratopteris thalictroides, Molecular Cloning - Selected Applications in Medicine and Biology, Prof. Gregory Brown (Ed.), ISBN: 978-953-307-398-9, InTech, Available from:

http://www.intechopen.com/books/molecular-cloning-selected-applications-in-medicine-and-biology/molecularcloning-and-characterization-of-fe-superoxide-dismutase-fe-sod-from-the-fern-ceratopteris-

\section{INTECH}

open science | open minds

\section{InTech Europe}

University Campus STeP Ri

Slavka Krautzeka 83/A

51000 Rijeka, Croatia

Phone: +385 (51) 770447

Fax: +385 (51) 686166

www.intechopen.com

\section{InTech China}

Unit 405, Office Block, Hotel Equatorial Shanghai

No.65, Yan An Road (West), Shanghai, 200040, China

中国上海市延安西路65号上海国际贵都大饭店办公楼405单元

Phone: +86-21-62489820

Fax: +86-21-62489821 
(C) 2011 The Author(s). Licensee IntechOpen. This is an open access article distributed under the terms of the Creative Commons Attribution 3.0 License, which permits unrestricted use, distribution, and reproduction in any medium, provided the original work is properly cited. 